$37^{\circ} \mathrm{C}$ in synthetic medium containing $80 \gamma$ of the factor per $\mathrm{ml}$. This treatment, however, did not result in an irreversible damage to the factor, as was shown by the fact that it could be reactivated through alkalization to $p \mathrm{H} 7 \cdot 3$ by the addition of sodium hydroxide. Using this reactivated factor a flattening quantitatively comparable to that obtained in the medium described in Table 1 was obtained.

From these results it can be concluded that the basic function of the active factor is that of a sodium donor, possibly for the transfer of carbon dioxide produced by the cells. These findings are also of interest with respect to the degree of adhesiveness of HeLa cells to a glass surface, which therefore depends on the $\mathrm{Na}$ - concentration on the surface ${ }^{6}$.

Tissue Culture Department,

Institute of Sera and Vaccines,

Prague, Czechoslovakia.

'Holmes, R., and Wolfe, S. W., J. Biophys. Biochem. Cytol., 10, 389 (1961). ${ }^{2}$ Michl, J., Exp. Cell Res., 23, 324 (1961).

${ }^{3}$ Michl, J., Neoplasma, Supp. 1, 7, 75 (1960).

4 Michl, J., Exp. Cell Res., 26, 129 (1962).

${ }^{5}$ Ledvina, M., Mukoproteidy v organismu (SZdN, Praha, 1958).

- Rappaport, C., Poole, J. P., and Rappaport, H. P., Exp. Cell Res., 20, $465(1960)$.

\section{Morphological Effects of Temperature on the Growth of Theobroma cacao}

THE effect of temperature on the growth of Theobroma cacao is being investigated in constant environment growth rooms ${ }^{1}$. The normal growth of cocoa is by production of flushes, and the rate of flushing, number of leaves per flush and the average size of leaf vary with environmental factors.

Field experimental work ${ }^{2}$ has associated size of leaf very largely with light intensity, cocoa being a crop usually grown under shade trees. In the work recorded here, cuttings of the clone ICS 95 were grown under similar conditions of light intensity and humidity but in one case at a temperature of $20^{\circ} \mathrm{C}$ and in the other at $32^{\circ} \mathrm{C}$. The appearance of the plants after 4 months in the rooms is shown in Fig. 1. At the lower temperature, apical flushes of 3-4 large leaves were produced. At the higher temperature, loss of apical dominance has occurred and a large number of axillary flushes carrying very small leaves has resulted.

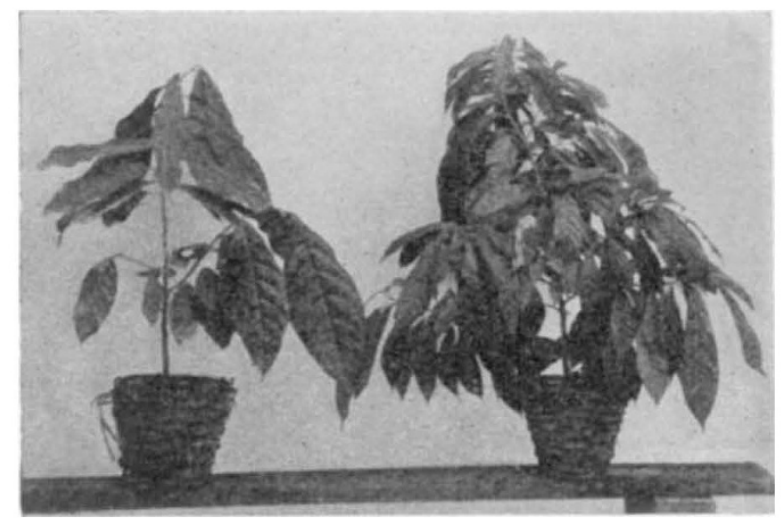

Fig. 1. T. cacao grown at $20^{\circ} \mathrm{C}$ (left) and at $32^{\circ} \mathrm{C}$ (right)

The appearance of the plants grown at the higher temperature is very similar to that of a plant grown in the field without shade, and growth of the plant at the lower temperature is similar to that of a plant grown under fairly heavy shade. The implication is that the morphological differences found botween plants grown with and without shade are a result of temperature differences and not light intensity as such.

\section{B. MURray}

Regional Research Centre,

University of the West Indies, Trinidad.

${ }^{1}$ Murray, D. B., Rep. Cacao Res., 1959-60, 11 (Imp. Coll. Trop. Agric., Trinidad, 1961).

${ }^{2}$ Evans, H., and Murray, D. B., Rep. Cacao Res. 1945-51, 67 (Imp. Coll. Trop. Agric., Trinidad, 1953).

\section{A Metabolite of Dacryomyces deliquescens (Duby)}

LABORATORY culture of the basidiomycete Dacryomyces deliquescens has been previously reported ${ }^{1}$. Aqueous malt cultures maintained at room temperature develop a sweetish odour which is sometimes reminiscent of apples. Large volumes of culture liquid have been distilled and extracted with benzene or alternatively with diethyl ether. Subsequent evaporation of either solvent followed by recrystallization from ethanol gave small prisms.

Absence of melting point and eventual charring of the product indicated an organic salt which was found to contain potassium by the flame and cobaltinitrite tests.

The odour of valeric acid was often noticed from staling cultures and more particularly when these were distilled. Acidity of the distillate was indicated using phenolphthalein.

Solutions of the potassium salts of valeric, isovaleric, butyric and isobutyric acids were prepared by neutralization with potassium carbonate. The odour of potassium valerate solution approached that of the culture liquid.

Crystals of potassium valerate prepared by neutralization of the acid with potassium carbonate, followed by distillation extraction with benzene or diethyl ether and subsequent recrystallization from ethanol, were identically similar to those of the fungus product.

I thank Prof. M. Stacey for his advice.

J. H. FIELD

Handsworth New Road

Boys' School,

Birmingham, 18.

${ }^{2}$ Field, J. H., Nature, 198, 907 (1963).

\section{An Extension of the Known Distribution of Eutypa armeniacae}

WHEN E. armeniacae Hansf. and Carter was described as the perfect stage of a known Cytosporina pathogen ${ }^{1}$, there was no record of the occurrence of a similar pathogen on apricot outside Australia. Soon afterwards, however, Dingley ${ }^{2}$ reported its presence in New Zealand after a collection referred to the Waite Institute had been matched with the type specimen.

Later, a Cytosporina morphologically similar to the Australian apricot pathogen was reported by English et $a l^{3}$ as the cause of apricot branch-killing in California, but not until Dr. W. H. English visited the Waite Institute in September 1962 was it possible to confirm its identity as the imperfect stage of $E$. armeniacae.

Flentje, who visited the Rhône Valley of France in 1949, noted symptoms identical with Cytosporina damage to apricot trees, and he cultured a fungus which he believed to be the same Cytosporina long known in Australia (personal communication). Some four years later, one of us (G. S. M.) photographed similar symptoms in this district of France.

In September 1963 we visited apricot orchards in the Rivesaltes and Avignon districts, and found abundant symptoms indicative of Eutypa damage. Although fructifications were not found, isolations from cankered branches yielded the Cytosporina stage, and subsequent 